\title{
REAKCIE SLOVENSKEJ KULTÚRNEJ OBCE NA SOVIETSKU KAMPAŇ PROTI TZV. FORMALIZMU V UMENÍ MEDZI ROKMI 1936 - 1938
}

\author{
FILIP PAV Č Í K
}

\begin{abstract}
PAVČÍK, Filip. Reactions of the slovak cultural community to the soviet campaign against so called formalism in the arts between the years 1936 and 1938. Historický časopis, 2019, 67, 1, pp. 103-125, Bratislava.

The study focuses on the reactions of the Slovak cultural community to the Soviet campaign against so-called formalism in the arts between the years 1936 and 1938. The paper analyses public reactions to the fabricated political trials and the subsequent persecutions and wide-ranging arrests of Soviet artists and intellectuals in the Slovak cultural journals. While the discussions among communist and L'udák intellectuals about Stalin's terror in the thirties have been the subjects of several historical studies, the opinions of Slovak liberal and democratic writers and intellectuals are barely known. Many of these writers shared communist ideas about the liberalization and democratization of the Soviet Union, although this cannot be completely generalized and depends on specific authors. The study wants to emphasize that the illusions and unrealistic ideas remained among them during the whole period of the thirties and also after the Second World War during the last part of the Stalin epoch.

Key words: Campaign against formalism. Soviet Union. André Gide. Slovak artists and intellectuals. Cultural journals.
\end{abstract}

DOI: https://doi.org/10.31577/histcaso.2019.67.1.5

Koncom mája 1936 sa v Sovietskom zväze konal pohreb jedného z najslávnejších ruských a sovietskych spisovatel’ov Maxima Gorkého. Zúčastnili sa na ňom viacerí významní zahraniční hostia, umelci a diplomati, vrátane francúzskeho spisovatel'a André Gidea․ Ten bol práve v tomto období na návšteve v Sovietskom zväze a pár mesiacov po návrate domov opísal svoje dojmy zo stalinistickej diktatúry v útlej knižke s názvom Retour de l'U.R.S.S (Návrat zo Sovietskeho $z v a ̈ z u)$. Kniha tohto l'avicovo-orientovaného Francúza a jeho kritika vtedajších

1 André Gide (1869 - 1951) - francúzsky prozaik, novinár a dramatik. Nositel’ Nobelovej ceny za literatúru za rok 1947. Na začiatku 30. rokov patril medzi sympatizantov (tzv. súputníkov) komunistického hnutia, avšak po vlastnej návšteve ZSSR v roku 1936 a po začiatku verejných politických monsterprocesov sa s komunistickým hnutím definitívne rozišiel. Bližšie k literárnej a publicistickej činnosti A. Gidea pozri: ČERNÝ, Václav. André Gide. Brno: Triáda, 2002, 399 s. ISBN 8086138119. 
sovietskych pomerov vzbudila mimoriadny rozruch po celej Európe, najmä však na l'avej strane politického spektra. Niežeby to bola prvá kniha kritizujúca ZSSR, ale napísal ju autor, ktorý len pár mesiacov predtým vyznal svoje sympatie a obdiv k „prvej krajine robotníkov a rolnikov" a v prejave na Gorkého pohrebe dokonca spojil osud svetovej kultúry s osudom Sovietskeho zväzu. ${ }^{2}$

Táto Gideova kniha bola bleskovo preložená do češtiny Bohumilom Mathesiom, ${ }^{3}$ a tak sa s ňou na prelome rokov 1936/1937 mohol zoznámit' aj český a slovenský čitatel'. Už na začiatku februára 1937 informovali sociálno-demokratické Robotnícke noviny, že vyšlo práve siedme vydanie tejto knižky a celkový náklad dosiahol úctyhodných 10000 kusov. ${ }^{4}$ Spolu s práve prebiehajúcimi monsterprocesmi v Sovietskom zväze (s bývalými poprednými bol'ševickými predstavitel'mi) $)^{5}$ podnietila táto kniha mimoriadne rušnú diskusiu na stránkach českej, resp. českojazyčnej tlače, ako na to poukázal v knihe Česká levice proti Moskvě (1936 - 1938) historik Ivan Pfaff. ${ }^{6}$

V predkladanej štúdii sa budem venovat' reakciám slovenskej kultúrnej obce na dianie v Sovietskom zväze medzi rokmi 1936 - 1938. V tomto krátkom období prebiehala ako súčast' sovietskeho Vel'kého teroru aj masívna kampaň proti

2 André Gide v prejave na Gorkého pohrebe doslovne povedal: „Na tomto Červenom námestí, ktoré videlo už tol'ko slávnych aj tragických udalostí, pred mauzóleom Leninovým, na ktoré uprene hl'adi tol'ko pohl'adov, slávne prehlasujem menom spisovatel'ov zhromaždených v Londýne [na medzinárodnej konferencii na obranu kultúry - F. P.] i menom svojím: starostlivost' a povinnost' kultúru bránit', ochraňovat' a znovu vzdelávat' pripadla vel'kým medzinárodným silám revolučným. Osud kultúry je v našich dušiach spojený s osudom Sovietskeho zväzu. Budeme ju bránit'. " Celý text prejavu pozri: GIDE, André. Řeč pronesená na Rudém náměstí v Moskvě při pohřbu Maxima Gorkého (20. června 1936). In GIDE, André. Návrat ze Sovětského svazu. Praha: Družstevní práce, 1936, s. 51.

3 Bohumil Mathesius (1888 - 1952) - český prekladatel', básnik a literárny kritik. Spoluzakladatel' legendárneho českého časopisu Literární noviny, ktorého bol v rokoch 1934-36 šéfredaktorom. Po druhej svetovej vojne pôsobil ako profesor na Karlovej univerzite v Prahe, kde vyučoval ruskú a sovietsku literatúru.

4 Jdv. 10000 exem. Gidovho „Návrat z SSSR“. In Robotnícke noviny, 2. 2. 1937, s. 4.

5 V auguste 1936 sa konal prvý verejný monsterproces so šestnástimi obžalovanými (proti G. Zinovjevovi, L. Kamenevovi a spoločníkom), v ktorom boli všetci obžalovaní odsúdení na trest smrti. Koncom januára 1937 padlo trinást' rozsudkov smrti (v procese proti K. Radkovi, G. Pjatakovovi a spol.) a nakoniec v poslednom procese, ktorý skončil 13. marca 1938 bolo odsúdených k smrti osemnást' obžalovaných vrátane N. Bucharina, A. Rykova a mnohých d'alších bývalých popredných lídrov Všezväzovej komunistickej strany - bol'ševikov. Bližšie pozri: PFAFF, Ivan. Česká levice proti Moskvě (1936 - 1938). Praha: Naše vojsko, 1993, s. 5. ISBN 8020603719.

6 PFAFF, ref. 5, s. 31-42 a n.

7 Vôbec prvý kto použil termín Vel'ký teror (the Great Terror) bol britský historik Robert Conquest a označil ním nielen tri vel'ké politické monsterprocesy s poprednými bol'ševickými revolucionármi, ale taktiež aj následnú a na procesy nadväzujúcu masovú perzekúciu, zatýkanie a vraždenie obyvatel'stva, vrátane cenzúry diel moderných a avantgardných umelcov. 
tzv. formalizmu v umení, ktorá bola namierená proti avantgardným a modernistickým umelcom s ciel'om ovládnut' kultúrny a spoločenský život v Sovietskom zväze. Verejné reakcie na vykonštruované politické procesy, zakazovanie, príp. cenzurovanie modernistických umeleckých diel a následnú perzekúciu umeleckých tvorcov budem sledovat' na stránkach slovenských (resp. slovenskojazyčných) umeleckých periodík a v kultúrnych rubrikách denníkov politických strán. Pritom ma ale primárne nebudú zaujímat' postoje a reakcie komunistických a l'udáckych autorov, ktoré sú viac-menej známe a boli predmetom viacerých analýz. ${ }^{8}$ Pomerne málo známe a o to zaujímavejšie sú ohlasy politicky nevyhranených umelcov a publicistov, ktorí nezaujímali a priori negatívne alebo len výhradne pozitívne stanoviská k bol'ševickému režimu na základe svojej straníckej/konfesionálnej alebo inej príslušnosti. Viacerí z nich totiž perzekúcie sovietskych tvorcov minimálne vo verejne dostupných vyjadreniach v tlači vedome relativizovali alebo sa $\mathrm{k}$ perzekúciám a cenzúre diel aj svojich priatel'ov vôbec nevyjadrovali. Mnohí autori si pri komentovaní diania v Sovietskom zväze všímali skôr iné „pozitívne“ zjavy sovietskeho života, akým bolo napr. prijatie novej ústavy v decembri 1936 interpretovanej ako jeden z viditel'ných dôkazov o demokratizácii a liberalizácii spoločenského života v ZSSR. ${ }^{9}$

Ohlasy slovenských intelektuálov, umelcov a predstavitel'ov politických strán na monsterprocesy i perzekúciu sovietskych tvorcov samozrejme nie sú v slovenskej historiografii neznáme. Jednu z najpodrobnejších a najoriginálnejších prác na danú tému napísala historička Dagmar Čierna-Lantayová v monografii Pohl'ady na východ (Postoje k Rusku v slovenskej politike 1934 - 1944). Pre-

K tomu pozri: CONQUEST, Robert. Velký teror. Nové zhodnocení. Praha: Academia, 2002, s. 16-44. ISBN 9788020020789. Rovnako ruský historik Oleg Chlevňuk pod termínom Vel'ký teror chápe štátom organizovanú masovú perzekúciu, zatýkanie a popravy sovietskeho obyvatel'stva, ako aj masovú čistku v rámci Všezväzovej komunistickej strany - bol’ševikov VKS (b). CHLEVNYUK, Oleg. The Objectives of the Great Terror, 1937-1938. In HOFFMANN, David L. (ed.). Stalinism. The Essential Readings. Oxford; Malden: Blackwell Publishers Ltd., 2003, s. 83. ISBN 063122890.

8 Ak sa aj v štúdii na niekol'kých miestach venujem autorom $\mathrm{z}$ prostredia davistov alebo l'udákov, robím tak iba $\mathrm{v}$ tom prípade, ak ich postoje a názory neboli doteraz $\mathrm{v}$ historiografii predmetom odbornej analýzy. K recepcii názorov l’udáckych a komunistických (resp. davistických) publicistov pozri napr.: ZEMKO, Milan. Slovenskí vzdelanci v spore o Sovietske Rusko tridsiatych rokov. In IVANTYŠYNOVÁ, Tatiana a kol. Mýtus - stereotyp - obraz. Rusko v slovenských dejinách a kultúre. Bratislava: Spoločnost' pre dejiny a kultúru strednej a východnej Európy, 2011, s. 56-67; DRUG, Štefan. DAV a davisti. Bratislava: Tatran, 1965, s. 118-121; JAKSICSOVÁ, Vlasta. Komunistický intelektuál - vít’az i porazený hodnotového sporu v „medzičase“ pred komunistickou diktatúrou. In Historický časopis, 2014, roč. 63, č. 1, s. 75-77. ISSN 0018-2575.

9 Takto interpretoval novú sovietsku ústavu agrárnický Slovenský deník. K tomu pozri: Nová ruská ústava upevňuje svetovú demokraciu. In Slovenský denik, 19. 6. 1936, s. 1. 
svedčivo v nej zobrazila ilúzie a nereálne predstavy, aké mala slovenská (najmä) l'avicová inteligencia i predstavitelia vládnych politických strán pri posudzovaní pomerov panujúcich v ZSSR, najmä od polovice 30. rokov: po vstupe Sovietskeho zväzu do Spoločnosti národov, po skoncovaní s politikou šírenia revolúcie či po podpísaní československo-sovietskej spojeneckej zmluvy v máji 1935. Hoci autorka v závere konštatovala, že ilúzie o demokratizácii Sovietskeho zväzu po Vel'kom terore $\mathrm{v}$ rokoch 1936 - 1938 postupne opadli, v d'alšom texte ukážem, že tomu tak celkom nebolo. ${ }^{10}$ Predstavy o uvol’ňovaní a liberalizácii pomerov v ZSSR totiž pretrvávali aj počas ,teroru“ (dokonca boli interpretované ako súčast' demokratizácie), hoci to nie je možné úplne zovšeobecnit' a záviselo to od konkrétnych autorov, resp. od ich schopnosti zorientovat' sa v sovietskych pomeroch.

\section{Kampaň proti tzv. formalizmu ${ }^{11} v$ umení - súčast' sovietskeho Vel'kého te- roru}

Kritické hlasy a verbálne útoky v tlači voči moderným a avantgardným umelcom a ich dielam sa v Sovietskom zväze objavovali po celé medzivojnové obdobie. Už v roku 1925 vzniklo Ruské združenie proletárskych spisovatel'ov (RAPP), ${ }^{12}$

10 ČIERNA-LANTAYOVÁ, Dagmar. Pohl'ady na východ (Postoje k Rusku v slovenskej politike 1934 - 1944). Bratislava: VEDA, 2002, s. 69. ISBN 802240716.

11 Pojem formalizmus má svoj názov odvedený od ruskej formálnej školy, ktorá vznikla na začiatku 20. storočia. Ide o literárno-vedný smer, ktorý mal v ruskom prostredí prispiet' $\mathrm{k}$ zvedečteniu literárnej kritiky a literárnej vedy, v tom čase poznačenej pozitivizmom a metodologickým eklektizmom. Pri vedeckej analýze literárneho diela formalizmus využíval lingvistické metódy a zdôrazňoval najmä estetickú funkciu literatúry a zákonitosti textovej štruktúry diela. Ruskí formalisti pôsobili najmä v dvoch organizačných spolkoch: Moskovskom lingvistickom krúžku a v petrohradskom Spolku pre skúmanie básnického jazyka (známym aj pod skratkou OPOJAZ). Medzi najvýznamnejších predstavitel'ov patrili: Roman Jakobson a Piotr Bogatyrov (ktorí po emigrácii pôsobili aj v Československu), Viktor Šklovskij a d’alší. V čase vykonštruovaných stalinistických procesov a ideologických kampaní boli ruskí formalisti označení za propagátorov samoúčelného „čistého umenia“a „buržoázneho idealizmu“. Pojem formalizmus tak od 30. rokov nadobudol dehonestujúci vulgárny výraz a jeho predstavitelia (i nimi ovplyvnení autori) boli terčom perzekúcie a útokov zo strany politickej moci. Myšlienky ruských formalistov rozvíjal v Československu Pražský lingvistický krúžok a bratislavský Spolok pre vedeckú syntézu. Viac k tomu pozri: PAŠTEKOVÁ, Soňa. Ruský formalizmus. Dostupné na internete: http://hyperlexikon.sav.sk/sk/pojem/zobrazit/autor/7/rusky-formalizmus [cit. 2018-08-30].

12 Rossijskaja associacija proletarskich pisatelej (RAPP) - bola vplyvná spisovatel'ská organizácia, ktorá v Sovietskom zväze pôsobila v rokoch 1925 - 1932. Tvorili ju najmä komunistickou stranou podporovaní radikáli v literárnej obci a medzi jej najznámejších predstavitel’ov patrili napríklad: Leopold L. Averbach (1903 - 1937), Vladimir M. Kirschon (1902 - 1938) či z československého prostredia známy Alexander A. Fadejev (1901 - 1956). Viac k združeniu RAPP pozri: CLARK, Katherina. Sovětský román. Dějiny jako rituál. Praha: Academia, 2015, 
ktoré žiadalo radikálne čistky a cenzúru v kultúrnej sfére. Jeho predstavitelia článkami v tlači napádali ostatných, najmä modernistických spisovatel'ov nezapadajúcich do ich definície „proletárskeho umenia“, ktoré sami považovali za jediné prípustné. Práve pod záštitou RAPP-u sa v roku 1930 konala v Charkove medzinárodná konferencia „revolučných spisovatel'ov“, na ktorej bol socialistický realizmus (ako nástupca ,proletárskeho umenia“) vyhlásený za jedinú záväznú smernicu umeleckej tvorby: všetky ostatné, najmä moderné umelecké smery, boli označené za „sektárske“ a vyhlásené za „trockistickú úchylku“. Takéto radikálne postoje a názory boli však napokon vedením komunistickej strany odmietnuté a združenie RAPP bolo v roku 1932 rozpustené. ${ }^{13} \mathrm{Na}$ jeseň 1934 sa potom v Moskve konal prvý zjazd Zväzu sovietskych spisovatel'ov, ktorý potvrdil socialistický realizmus ako dominantný smer pre komunistických umelcov, no k modernému umeniu sa postavil zhovievavejšie ako predošlá konferencia v Charkove. ${ }^{14}$ Až o dva roky neskôr, v súvislosti s prebiehajúcim Vel'kým terorom, začalo byt' moderné umenie likvidované celoštátne a moderná umelecká tvorba bola spájaná s ,protištátnymi“ aktivitami nepriatel'ov režimu - „trockistami““ či „pravicovými oportunistami“.

Samotná „protiformalistická“ kampaň, v zmysle otvorenej kultúrnej vojny, začala už koncom januára 1936 dvoma anonymnými článkami na stránkach moskovskej Pravdy. Tie verbálne odsúdili Šostakovičovu ${ }^{15}$ operu Lady Macbeth Mcenského újezdu a balet Jasný potok a obvinili sovietskeho skladatel'a z komponovania „chaosu“ miesto prirodzenej l'udskej hudby. Táto opera i balet boli okamžite stiahnuté z repertoáru v celom Sovietskom zväze a vyššie spomenuté články poskytli zámienku aj na výpady voči avantgardnému divadelnému režisérovi Vsevolodovi Mejercholdovi. ${ }^{16}$ Jeho divadlo bolo potom definitívne zrušené začiatkom roku $1938 .{ }^{17}$ Avšak kultúrna čistka sa netýkala iba dramatického

s. 56-59. ISBN 9788020024039.

13 CLARK, ref. 12, s. 57.

14 DRÁPALA, Milan. Iluze jako osud. K vývoji politických postojů Vítězslava Nezvala. In Soudobé dějiny, 1996, roč. 3, č. 2-3, s. 188-189. ISSN 2336-3142.

15 Dmitrij Dmitrijevič Šostakovič (1906 - 1975) - ruský a sovietsky hudobný skladatel', jeden z najvýznamnejší predstavitel'ov svetovej hudobnej moderny v 20. storočí. Jeho diela boli v Sovietskom zväze častým terčom cenzúry i vulgárnych útokov od straníckych ideológov.

16 Vsevolod Emilievič Mejerchold (1874 - 1939) - ruský avantgardný divadelný režisér a popredný predstavitel' štylizovaného divadla. Po bol'ševickom prevrate v roku 1917 vstúpil do Všezväzovej komunistickej strany (bol’ševikov), no stalinistickým čistkám v strane sa nevyhol. V júni 1939 bol zatknutý a 2. februára 1940 zastrelený. Jeho manželka a herečka Zinaida Reichová bola zavraždená už o rok skôr, krátko po jeho zatknutí. Bližšie pozri: CONQUEST, ref. 7, s. 458.

17 CLARK, Katherina. Moskva, Čtvrtý Řim. Stalinizmus, kosmopolitismus a vývoj sovětské kultury 1931-1941. Praha: Academia, 2016, s. 304-305. ISBN 9788020025890. 
umenia. Ešte v roku 1936 bolo z moskovskej Tret’jakovskej galérie ${ }^{18}$ stiahnutých množstvo modernistických výtvarných diel, no „teror“ zrejme najviac postihol sovietskych spisovatel'ov. Podl'a historika Roberta Conquesta si v rokoch 1936 1938 vyžiadal vyše 500 obetí. $^{19}$

Celoštátne riadenú akciu proti formalizmu v umení mal na starosti špeciálny úrad - Všezväzový komitét pre záležitosti umenia, vytvorený vo februári 1936 práve pre potreby čistky v sovietskom umeleckom živote. Dané udalosti v Sovietskom zväze mali mimoriadnu rezonanciu aj na stránkach českých kultúrnych časopisov a vyvolali značne konfliktnú polemiku medzi zástancami (spravidla komunistickými ideológmi) a odporcami čistiek. Podl'a českých historikov Ivana Pfaffa, Alexeja Kusáka a Milana Drápalu to vyústilo až do krízy českej l'avicovej kultúry, z ktorej sa do vypuknutia druhej svetovej vojny celkom nespamätala. ${ }^{20}$

$\mathrm{Na}$ druhej strane je zaujímavé, že slovenské kultúrne periodiká sovietsku „protiformalistickú" kampan̆ takmer vôbec nereflektovali (a to isté platilo aj pri nacistickej kampani vedenej proti „zvrhlému umeniu“ či „kultúrnemu bol’ševizmu“). Kým na českej strane vyšli minimálne tri samostatné knižky reflektujúce a analyzujúce udalosti $v$ ZSSR, ${ }^{21}$ jedna divadelná hra zosmiešňujúca postavenie umelca $v$ súdobej sovietskej diktatúre ${ }^{22}$ a jeden satirický román ${ }^{23}$ tak na Slovensku (až na brožúru Odpoved' A. Gideovi od komunistu a davistu Eugena Löbla) nevyšlo o horúcich udalostiach v sovietskej kultúre či politike takmer nič, okrem zopár článkov roztrúsených po rôznych periodikách. Dôvody, pre ktoré tomu tak bolo, budú predmetom nasledujúcich riadkov.

18 Tret’jakovská štátna galéria v Moskve je jedna z najvýznamnejších galérií ruského výtvarného umenia. Už v roku 1856 ju založil mecenáš a zberatel' umeleckých diel Pavol Michailovič Tret’jakov (1832 - 1898), ktorý bol zároveň aj jej prvým riaditel’om.

19 Neuveritel'ne početnú masovú perzekúciu medzi sovietskymi spisovatel’mi dobre ilustruje skutočnost', že pokým prvého zjazdu Zväzu sovietskych spisovatel'ov sa v roku 1934 zúčastnilo sedemsto literátov, tak druhého zjazdu, ktorý sa konal o dvadsat' rokov neskôr, sa dožilo iba pät'desiat z nich. K tomu pozri: CONQUEST, ref. 4, s. 445. K ,protiformalistickej“ kampani a k čistkám v sovietskom umeleckom živote tiež: PFAFF, ref. 5, s. 87-89; CLARK, ref. 17, s. 303-308.

20 PFAFF, ref. 5, s. 87-89; KUSÁK, Alexej. Kultura a politika v Československu v letech 1945 - 1968. Praha: Torst, 1996, s. 121-122. ISBN 8072150553; DRÁPALA, ref. 14, s. 175-218.

21 Uvádzam v chronologickom poradí v akom vyšli: Josef Guttman - Záviš Kalandra: Odhalené tajemství moskevského procesu (1936); Stanislav Kostka Neumann: Anti-Gide neboli optimism bez pověr a ilusí (1937); Karel Teige: Surrealismus proti proudu (1938).

22 Hamlet III. od režiséra Emila Františka Buriana.

23 Román Moskva-hranice od Jiř́ího Weila. Vel'mi nelichotivo ho recenzoval napríklad Ladislav Novomeský v Slovenský zvestiach. Pozri: -ý-. Zlé románové svedectvo o SSSR. In Slovenské zvesti, 23. 12. 1937, s. 6 . 


\section{Reakcie slovenských umelcov na dianie v Sovietskom zväze medzi rokmi 1936 - 1938}

Podl’a slovenskej historičky Dagmar Čiernej-Lantayovej vládla na Slovensku od polovice 30. rokov atmosféra nekritického obdivu k ZSSR, ktorá vyvrcholila počas návštevy sovietskych spisovatel'ov Bratislavy a iných slovenských miest v októbri $1935 .{ }^{24}$ Tejto romanticky naivnej náklonnosti neostali ušetrení ani umelci, od ktorých by sa to z dnešného pohl'adu určite neočakávalo. Tak napríklad Tido J. Gašpar nielenže otváral manifestačné matiné v Slovenskom národnom divadle počas Dní sovietskej kultúry, ktoré sa konali v tom istom roku, ale dokonca sa vo svojom pravidelnom stípčeku v obrázkovom časopise $N o v y ́$ svet chválil, že „, nie je novopečným, módnym ani konjunkturálnym priatelom týchto našich ruských vierozvestcov. Ja som nečakal až toto priatel'stvo bude vládnovrchnostensky schválené a stane sa ,salonfähig'. Naopak, ja som už hodne dávno, pred niekol'kými rokmi, ked' táto cesta bola ešte vel'mi zarúbaná, išiel do Carltonu na čaj, ktorý dával vtedajši pražský zástupca Sovietov, Ovsejenko. [...] Od tých čias sme sa úžasne rozmnožili a nastala vel'ká konjunktúra v priatel'stve $k$ sovietom. V Carltone na príklad, boli už všetky miesta plne obsadené ". ${ }^{25}$ No treba povedat', že takéto a podobné sympatie k Sovietskemu zväzu neboli na stránkach Nového sveta, ktorý v tom čase redigovali konzervatívni publicisti Konštantín Čulen a Jozef Rudinský, ani zd’aleka bežné. ${ }^{26}$

Spomínané Dni sovietskej kultúry, ktoré sa konali mesiac po odchode delegácie sovietskych spisovatel'ov z ČSR, vyvrcholili premiérou Šostakovičovej opery Lady Macbeth Mcenského újezdu, ktorá bola nadšene prijatá kultúrnymi rubrikami denníkov slovenských vládnych strán. ${ }^{27}$ Iba katolícke a l'udácke denníky vtedy kritizovali operu $\mathrm{z}$ antimodernistických konzervatívnych pozícií. ${ }^{28} \mathrm{To}$ však nebolo prekvapivé, ked’že sa neustále negatívne vymedzovali voči (ateis-

24 ČIERNA-LANTAYOVÁ, ref. 10, s. 53.

25 GAŠPAR, Tido J. O čom je reč? In Nový svet, 2. 11. 1935, roč. 10, č. 39, s. 3-4.

26 Gašparovu účast' na sovietskych slávnostiach s vel'kou nevôl'ou sledovali najmä katolícke a konzervatívne denníky a časopisy. Rozhorčene na ňu reagoval hlavný redaktor revue Kultúra Karol Körper. K tomu pozri: KÖRPER, Karol. Úlohy katolíckych Slovákov. In Kultúra, 1936, roč. 8, č. 1, s. 29.

27 Pozri napr.: BRTÁŇ, Rudolf. K premiére opery „Ruská lady Macbeth“. In Slovenský deník, 23. 11. 1935, s. 4. i. b. Ruská Lady Macbeth (K dnešnej premiére na Slov. nár. divadle). In Slovenský denik, 23. 11. 1935, s. 3; BALLO, Ivan. Európska udalost' v opere Slov. nár. divadla (Premiéra Šostakovičovej opery „Ruská Lady Macbeth“ 23. XI.). In Slovenský deník, 26. 11. 1935, s. 5. Pod iniciálkam i. b. sa ukrýval divadelný a operný kritik Ivan Ballo.

28 Pozri: Bol’ševická opera. In Slovák, 26. 11. 1935, s. 2. Taktiež pozri Machovu recenziu po zahájení „,protiformalisitickej“ kampane v ZSSR: MACH, Šaňo. Bol’ševickí kamaráti, a čo teraz? In Slovák, 9. 2. 1936, s. 2. Na operu reagovali vel’mi nelichotivo, ako na „nemravný kus divadelný'“, aj v katolíckej revue Kultúra: KÖRPER, ref. 26, s. 29. 
tickému) sovietskemu režimu a jeho „revolučnej“ kultúre a nepriaznivo vnímali už len nadviazanie vzájomných československo-sovietskych kultúrnych stykov.

Sporná bola pre l'udáckych intelektuálov aj otázka povolenia prvej výstavy sovietskej knihy v Bratislave v apríli 1936. „, V rozpakoch som bol ako katolik a Slovák, či hlasovat'za [povolenie výstavy - F. P.]. No ked'som si pozrel výsta$v u$, presvedčil som sa, že sme dobre zrobili, ked'sme umožnili výstavu: na vlastné oči každý videl tú úbohost" ", napísal redaktor katolíckej revue Kultúra Ján Dafčík a nakoniec to v recenzii nekompromisne zhrnul: ,,Chceš vidiet' ruskú kultúru, chceš sa pýtat', čo vytvorili za devätnást' rokov, si zvedavý prečo zabili na milióny nevinných l'udí, prečo trpí ruský l'ud v najhnusnejšom otroctve? Ukážu ti Dneprostroj, traktory, tanky a lietadlá. Úbohost! “29

Rovnako negatívne a odmietavo sa konzervatívne a katolícke kultúrne časopisy (či už matičné alebo svätovojtešské) vyjadrovali aj o avantgardných umeleckých smeroch a ich slovenských predstavitel'och. ${ }^{30}$ Preto sa ich náhl'adom a názorom $v$ nasledujúcich riadkoch nebudem bližšie zaoberat'. Ich verejný postoj k ZSSR (a čiastočne aj k modernému umeniu) sa zmenil až v roku 1939, po vyhlásení Slovenského štátu a v dôsledku nemecko-sovietskeho paktu Molotov - Ribbentrop, čo už je však mimo mnou skúmaného obdobia. ${ }^{31}$

Rôznorodé názory na kultúrnu politiku v Sovietskom zväze publikovali najmä l'avicové a liberálno-demokratické kultúrne a kultúrno-politické časopisy. Agrárnické Prúdy publikovali na pokračovanie cestopis spisovatel’a Ela Šándora z návštevy v ZSSR, ktorý však bol napísaný mimoriadne nekriticky. Elo Šándor, člen agrárnej strany, bol koncom roku 1936 zvolený za predsedu Spoločnosti pre hospodárske a kultúrne styky so ZSSR a v predmetnom období sa stal mimoriadne aktívnym obrancom východného spojenca ČSR. Ked' v máji 1936 publikoval v Eláne výtvarník Martin Benka svoje zväčša pozitívne dojmy z ciest po ZSSR, pričom iba $\mathrm{v}$ poslednom odseku rozsiahleho článku vyjadril sklamanie nad ešte stále viditel'nou chudobou či údiv nad neopravenými budovami z čias občianskej

29 DAFČÍK, Ján. Výstava sovietskej knihy. In Kultúra, jún 1936, roč. 8, č. 6, s. 270-271. Na druhej strane treba povedat', že ak sovietsky systém a jeho kultúru l'udácki publicisti tvrdo kritizovali, tak voči nacistickej kultúrnej politike až tak kritickí neboli. V časopise Kultúra napr. pretlačili aj Goebbelsov novoročný prejav z roku 1936 s vel'mi zhovievavým komentárom. $\mathrm{K}$ tomu pozri: AMARAND, Boris. Novoročný prejav ministra dra Goebbelsa. In Kultúra, 1936, roč. 8, č.1, s. 44-46.

30 JAKSICSOVÁ, Vlasta. Kultúra v dejinách, dejiny v kultúre. Bratislava: VEDA, 2012, s. 97-114. ISBN 9788022412384. Pozri napr. recenzie katolíckej revue Kultúra: -po-. Rudolf Fabry: Ut’até ruky (recenzia). In Kultúra, 1936, ročník 8, č. 1, s. 24; REISEL, Vlado. Prečo nerozumiete modernej poézii. In Slovenské smery, 1937, roč. 5, č. 2, s. 51-54; B. \& Š. Povery o slovenskej literatúre. In Slovenské smery, 1938, roč. 5, č. 5-8, s. 307-310. Iniciálami B. \& Š. sa podpisovali mladí literárni kritici: Mikuláš Bakoš a Klement Šimončič.

31 K obdobiu po roku 1939 pozri: ČIERNA-LANTAYOVÁ, ref. 10, s. 124-132. 
vojny, hned' mu na to odpovedal Šándor svojimi pozitívnymi skúsenost'ami. ${ }^{32}$ Neskôr, v septembrovom a októbrovom rozhovore pre Pero, umelecký časopis mladých autorov, Šándor dôvodil, že na svojich cestách ,,nehl'adal krivdy $v$ ZSSR, ako to robia mnohí cudzinci " a porovnávanie pomerov v Sovietskom zväze, ktorý bol ešte len „vo výstavbe“, s ostatnou Európe vnímal ako nespravodlivé. Ďalej sa v interview zasvätene vyjadril, že v tejto krajine ,nenávidia západoeuróspky surrealizmus " a prejavil uspokojenie aj nad stiahnutím pre neho nezrozumitel'ných modernistických diel z Tretjakovskej galérie. ${ }^{33}$

Aj o rok neskôr, pri príležitosti 20. výročia Vel'kej októbrovej socialistickej revolúcie (avšak aj v čase najintenzívnejších čistiek), publikoval Šándor svoj už druhý a rozsiahly cestopis Bratislava - Moskva a v novembri 1937 potom v Slovenskom deníku nadšene písal o výchove mladých literátskych kádrov v Moskve, ktorí sa môžu stat' skutočnými „,inžiniermi l’udských duší “. ${ }^{34} \mathrm{~A}$ hoci tento spisovatel' priznával, že v Sovietskom zväze majú ešte stále nedostatok kvalitných spisovatel'ov, čistkami a teroristickými pomermi v sovietskej diktatúre to nezdôvodňoval. Knihu Bratislava-Moskva potom pozitívne recenzovali redaktor kultúrnej rubriky Robotníckych novín Josef Dvořák a aj spisovatel' Gejza Vámoš, pre ktorého to bol dokonca ,"najlepší a najstatočnejší cestopis “. ${ }^{35}$ „Elo Šándor napísaním tejto knihy vykonal u nás vážne dielo, ktoré musí byt rešpektované nie iba naším čitatel'stvom, ale i samou kultúrnou propagandou Sovietskeho zväzu. Pomer Šándorov k Zväzu je v tejto knihe vrelý, oceňujúci, ked' treba chápajúci a spojenecký. "36

Podobné postoje l'avicových (Vámoš, Dvořák) a v slovenskom prípade aj konzervatívnych (Šándor, Gašpar) publicistov sa dnes môžu zdat' až príliš nekritické, nebolo to však medzi európskymi intelektuálmi nijak neobvyklé. Zoznam intelektuálov predchnutých ilúziami o ZSSR je dostatočne dlhý (Romain Rolland, Lion Feuchtwanger, Bertolt Brecht, George Bernard Shaw - aby som vymenoval aspoň tých, ktorí verejne schval'ovali stalinistické monsterprocesy z ro-

32 BENKA, Martin. Niekol'ko dojmov zo SSSR. In Elán, 1936, roč. 6, č. 9 s. 7; ŠÁNDOR, Elo. Ešte o dnešnom SSSR. In Elán, 1936, roč. 6, č. 10, s. 9.

33 Sovietske Rusko a Amerika. Čo o nich hovoria naši spisovatelia: Elo Šándor a Konštantín Čulen. In Pero, 1936, roč. 5, č. 4, s. 3.

34 ŠÁNDOR, Elo. Výchova literárnych kádrov v Moskve. In Slovenský deník, 8. 11. 1937, s. 5.

35 Literát Vámoš sa stal $\mathrm{v}$ tomto období taktiež aktívnym obrancom Sovietskeho zväzu proti útokom zo strany najmä l’udáckych publicistov. K tomu pozri aj: BARBORÍK, Vladimír. Prozaik Gejza Vámoš. Bratislava: Slovak Academic Press, 2006, s. 160-173. ISBN 8080950032.

36 VÁMOŠ, Gejza. Bratislava-Moskva (recenzia). In Slovenské smery umelecké a kritické, 1937, roč. 5, č. 2, s. 74; Jdv. Elo Šándor v SSSR. In Robotnicke noviny, 21. 11. 1937, s. 4. Obe hodnotenia sa tak nijako neodlišujú od Novomeského pozitívnej recenzie v Slovenských zvestiach. Pozri: (-ý-). Slovenský cestopis po sovietskej krajine. In Slovenské zvesti, 19. 12. 1937, s. 6. 
kov 1936 - 1938) a je známe, že Stalinovi a ostatným sovietskym predstavitel’om nešlo len o politickú, resp. imperiálnu hegemóniu, ale aj o kultúrne prvenstvo v Európe. ${ }^{37}$ Práve spisovatelia mali v ZSSR špeciálne postavenie a špeciálne úlohy (ako to vytrvalo hlásala sovietska propaganda), na rozdiel napr. od nacistického Nemecka, kde sa verejne a so značnou publicitou pálili knihy nepohodlných autorov.

Túto skutočnost' koniec-koncov vyzdvihoval aj spomínaný Elo Šándor vo svojich cestopisoch. ${ }^{38}$ Moskva 30. rokov predstavovala podla americkej kultúrnej historičky Katheriny Clark pre spisovatel'ov akýsi „štvrtý Rím“, ktorý sl’uboval intelektuálom novú kultúru, t. j. kultúru adekvátnu „,novej beztriednej spoločnosti“. Sovietski literáti typu Il'ju Erenburga, ${ }^{39}$ Michaila Kol'cova ${ }^{40}$ či Sergeja Tret'jakova ${ }^{41}$ vytrvale propagovali vytvorenie „,svetovej literatúry“, ktorej dominantný výraz mali samozrejme udávat' sovietski, resp. komunistickí literáti. ${ }^{42}$ Toto všetko však len čiastočne vysvetluje, prečo mohli Šándor (a aj Vámoš či Dvořák) písat' v čase najtvrdšej cenzúry a najintenzívnejších čistiek, že v ZSSR „, sa spisovatelia majú najlepšie zo všetkých pracovníkov “, ${ }^{43}$ či odsudzovat' modernú tvorbu ako nezrozumitel'nú a tým relativizovat' prebiehajúcu ,protiformalistickú" kampan̆.

37 K priaznivému vnímaniu Sovietskeho zväzu európskymi intelektuálmi bližšie pozri: CLARK, ref. 17, s. 310; FURET, Francois. Minulost' jednej ilúzie. Esej o idei komunizmu v 20. storoč́ Bratislava: Agora, 2000, s. 337-357. ISBN 8096721046; JUDT, Tony - SNYDER, Timothy. Intelektuál ve dvacátém století. Praha: Prostor, 2013, s. 191-201. ISBN 9788072602896.

38 ŠÁNDOR, Elo. Bratislava - Moskva. Bratislava: Nakladatel'stvo Slovenskej ligy, 1945, s. $120-135$.

39 Ilja Grigorievič Erenburg (1891 - 1967) - sovietsky básnik, prozaik a novinár. Patril medzi popredných predstavitel’ov sovietskej literatúry podporovaných straníckym vedením komunistickej strany. Počas španielskej občianskej vojny a druhej svetovej vojny pôsobil ako vojnový korešpondent. Erenburg sa priatelil s mnohými európskymi, ale i českými a slovenskými (najmä komunistickými) intelektuálmi a v československom prostredí tak bol mimoriadne známy.

40 Michail Jefimovič Kol'cov (1898 - 1940) - sovietsky spisovatel', novinár a vydavatel'. Do Všezväzovej komunistickej strany (bol’ševikov) vstúpil už v roku 1918 a v medzivojnovom období patril medzi prominentných redaktorov moskovskej Pravdy. Roku 1935 bol na čele delegácie sovietskych novinárov pri návšteve Československa. Neskôr, v období stalinského „Vel'kého teroru“, sa vo svojich článkoch zasadzoval o najprísnejšie tresty pre obžalovaných v politických monsterprocesoch a napokon sa v roku 1940 aj on sám stal obet'ou čistiek.

41 Sergej Tret’jakov (1892 - 1937) - sovietsky spisovatel', novinár a fotograf. Patril do skupiny avantgardných konštruktivistických spisovatel'ov združujúcich sa okolo časopisu LEF (Levy Front Iskusstv - L'avý front umenia). V polovici 30. rokov sa zúčastnil zájazdu sovietskych spisovatel'ov do Československa, no už o dva roky neskôr sa nevyhol stalinským čistkám. V júli 1937 bol zadržaný tajnou políciou a obvinený zo špionáže. Popravený bol 10. septembra 1937. CLARK, ref. 17, s. 55-58.

42 CLARK, ref. 17, s. 255-6.

43 ŠÁNDOR, ref. 38, s.130. 
Skutočnost'ou tak zostáva, že sa za perzekvovaných sovietskych umelcov nikto z významných slovenských kultúrnych činitel'ov nepostavil a sovietske kultúrno-politické pomery nikto verejne neodsúdil. Práve naopak, v roku 1937 boli v ČSR na programe mohutné oslavy: najprv vo februári 100. výročie smrti básnika A. S. Puškina a neskôr, v novembri, 20. výročie Vel'kej októbrovej socialistickej revolúcie (VOSR). Dňa 10. februára 1937, počas Puškinovských osláv, vydal celorepublikový Zväz priatel'ov ZSSR v spolupráci so sovietskym vyslancom Sergejom Sergejevičom Alexandrovským pamätnú publikáciu Věčný Puškin. Prispeli do nej českí, slovenskí i nemeckí literáti (zo slovenských: Ján Jesenský, Hana Gregorová a Ladislav Novomeský). ${ }^{44}$ Oslavy, ktoré sa konali aj v Bratislave či v Košiciach zapín̆ali stránky slovenských denníkov, čím len posilňovali romantické ilúzie o východnom spojencovi ČSR.

Počas puškinovských osláv sa k umeleckému životu v Sovietskom zväze vyjadril aj slovenský divadelný režisér Andrej Bagar. V časopise $U-B l o k^{45}$ konštatoval, že , umenie má byt' a musí byt' najslobodnejším prejavom umelca a to $v$ najširšom zmysle slova". Na základe vlastných skúseností získaných počas návštevy Sovietskeho zväzu pred štyrmi rokmi dokazoval, že ,, spôsob umeleckého prejavu je v ZSSR výlučne záležitost'ou umelcov. Od najživotnejšieho realizmu až po najmožnejšie vyhrotenie experimentalizmu má herec možnost' v akejkol'vek forme prejavit' a prezentovat' svoju umeleckú potenciu " ${ }^{46}$ Je však vel'mi nepravdepodobné, že by Bagar o „protiformalistickej“ kampani, ktorá zasiahla mnohých divadelníkov na čele so Vsevolodom Mejercholdom (a na ktorú upozorňoval aj český divadelný režisér Emil František Burian) ${ }^{47}$ nemal vedomost'.

44 HALAS, František - KUBKA, František (eds.). Věčný Puškin. Praha: Vydal vyslanec SSSR v Praze S. S. Alexandrovskij, 1937, 76 s.

45 Časopis U-Blok bol štvrt'ročník, ktorý združoval komunistických spisovatel'ov skupiny BLOK hlásiacich sa k socialistickému realizmu. Redigovali ho spisovatelia: Peter Jilemnický, Jan Noha, Bedřich Václavek, Jiří Taufer a český filozof Ludvík Svoboda. Zo slovenských spisovatel’ov boli členmi skupiny iba Ján Poničan a Fraňo Král'. Pozri: Pozdravný dopis československých spisovatelů, členů skupiny BLOK plenárnímu zasedání vedení Svazu sovětských spisovatelů v Minsku z 3. února 1936. In KRÁL, Václav et al. Dokumenty a materiály k dějinám československo-sovětských vztahů. Díl III. (červen 1934 - březen 1939). Praha: Academia, 1979, s. 244-5.

46 Na anketovú otázku časopisu U-Blok: „Čím je protifašistickému umělci a spisovateli SSSR?“ podobne odpovedali aj ostatní slovenskí, resp. po slovensky píšuci umelci: Ján Poničan, Fraňo Král' a Peter Jilemnický.

47 Emil František Burian v príležitostnom zborníku československých prejavov venovaných Sovietskemu zväzu nezabudol vzdat' hold V. Mejercholdovi, ako významnému sovietskemu umelcovi a aspoň symbolicky tak pripomenút vyslancovi Alexandrovskému situáciu okolo tohto umelca, voči ktorému už vtedy prebiehala zastrašovacia kampaň. Toto jeho vyjadrenie bolo v celom zborníku ojedinelé. Pozri: NEJEDLÝ, Zdeněk - GALLAS, Jan - RIPKA, Hubert (eds.). Československo Sovětskému svazu k 20. výroči (Sborník projevio). Praha: Společnost pro kulturní a hospodářské styky s SSSR, 1937, s. Do zborníka prispeli aj slovenskí 
Preto je jeho vyjadrenie o údajnej slobode umeleckého prejavu v ZSSR o to zarážajúcejšie. ${ }^{48}$

Aj dvadsiate výročie VOSR sa na stránkach slovenských denníkov nieslo $\mathrm{v}$ oslavnom duchu, hoci bolo čo kritizovat'. Na prelome októbra a novembra 1937 bola totiž v Moskve organizovaná výstava československého umenia, reprezentovaná širokou škálou českých i slovenských tvorcov, medzi ktorými boli zastúpené aj obrazy Martina Benku a L'udovíta Fullu. Architekt Jaromír Krejcar následne v Př́tomnosti informoval o cenzúre tejto výstavy a nezverejnení diel niektorých autorov, ktoré boli označené ako „formalistické“ (vrátane dvoch obrazov L'. Fullu) ${ }^{49}$ Táto informácia rozprúdila vášnivú polemiku v českých periodikách, no mnou sledované kultúrne rubriky slovenských denníkov i slovenské kultúrne časopisy túto udalost' prešli mlčaním. ${ }^{50}$ Strach z kritizovania československého spojenca bol potom badatel'ný aj pri hodnotení Gideovej kritiky Sovietskeho zväzu.

\section{Slovenské odpovede André Gideovi}

André Gide v spomenutej knižke Retour de l'U.R.S.S síce nešetril slovami chvály a obdivu pri budovaní novej komunistickej spoločnosti, avšak hlavne tvrdo kritizoval niekol'ko skutočností: predstieraný kolektivizmus a vynucovanie súhlasu na manifestáciách, uniformitu a konformizmus sovietskych občanov, kult vodcu Stalina či nemožnost' slobody tvorby. Najväčší rozruch však vzbudilo jeho prirovnanie vtedajšej sovietskej diktatúry k tej nacistickej: „Pochybujem, že by dnes v ktorejkol'vek inej krajine, vrátane hitlerovského Nemecka, bol človek menej slobodný, zhrbenejší, bojazlivejši (vydesenejší), podrobenejšì", vyhlásil. ${ }^{51}$

Ako prví sa k novej Gideovej knihe zo slovenskej strany vyjadrili komunistickí intelektuáli - davisti. Eugen Löbl (píšuci pod pseudonymom J. Les) najskôr v Slovenských zvestiach bránil Gidea pred fašistickými a liberálno-demokratickými (v jeho podaní „meštiackymi“) komentátormi jeho knihy s poukazom, že

autori: Vladimír Clementis, Bohdan Pavlů, Ladislav Novomeský, Hana Gregorová, Elo Šándor, Ivan Hálek, Ján Poničan.

48 Navyše, v septembri 1936 (teda už po prvom monsterprocese) sa slovenský divadelný súbor zúčastnil na moskovskom divadelnom festivale. Námietka, že slovenskí divadelníci nemali informácie o sovietskych divadelných pomeroch neobstojí. K tomu pozri aj: PAVLOVÁ-KRNOVÁ, Féd’a. Osud Meyerholdovho divadla. In Elán, 1938, roč. 8, č. 7, s. 7. A taktiež: Článek J. R. Poničana v Slovenských zvestech o kultúrních stycích slovensko-sovětských zo 7. 11. 1937. In KRÁL, Václav et al. Dokumenty a materiály k dějinám československo-sovětských vztahů. Díl III. (červen 1934 - březen 1939). Praha: Academia, 1979, s. 393-395.

49 KREJCAR, Jaromír. Oficiální výstava čsl. umění v SSSR - censurována sovětskými úřady. In Prítomnost, 10. 11. 1937, s. 6.

50 Celú kauzu podrobne rozoberá: PFAFF, ref. 5, s. 108-111.

51 GIDE, ref. 2, s. 53-54. 
ešte stále stojí na „pôde revolúcie“ a „, na tom nič nemení, že čo sa do pojmu revolučnosti s ním rozchádzame ". ${ }^{52}$ Neskôr, v publikovanej brožúre Odpoved” A. Gideovi, už bol podstatne kritickejší, no napriek tomu je v celej knižke badatel'ný mimoriadny obdiv $\mathrm{k}$ francúzskemu autorovi a zároveň hlboké sklamanie $\mathrm{z}$ jeho postoja. „Čo nás najviac bolí v Gideovej knihe, nie sú jeho omyly a vôbec nie to, že reakčníci rôznych odtieňov budú chciet' politicky t'ažit'z tejto knihy. Nie, to nás nebolí. Ale boli nás, že práve André Gide, ktorý sa vedel postavit' proti vlastnej triede, ked' spoznal, že pravda je na druhej strane, že André Gide, ktorý vedel byt' tak odváżne úprimný ako máloktorý spisovatel, že tento André Gide luhal. "53

V publikácií Löbl kritizoval najmä Gideovu neznalost' ruského jazyka a poukazoval aj na údajne nepresné informácie uvádzané v knihe. „Kriticky“ sa pozastavil práve nad konformizmom sovietskych občanov, ktorý interpretoval naozaj svojským spôsobom. Podl'a Löbla bol totiž Gideom kritizovaný konformizmus v komunistickej krajine výsostne pozitívny jav, pretože to bol konformizmus „revolučnýc“ a „proletársky“, zatial’ čo v kapitalistickej spoločnosti má konformizmus „buržoázny“ a „reakčný“ obsah..$^{54}$ Gide, ktorý sa vraj na sovietsku realitu pozeral očami „malomeštiaka“ a ,individualistu“, tak podl’a Löbla nemohol hodnotit' tento jav skutočne objektívne. V závere knihy však slovenský intelektuál vyjadril nádej, že jeho názory sú iba krátkodobou názorovou odchýlkou a že tento vel'ký duch sa vráti spät' k svojim predchádzajúcim stanoviskám. ${ }^{55}$

Bolo len prirodzené, že Löblova kniha sa musela zdat' málo kritická ortodoxnému komunistickému vedeniu strany, ba aj samotným davistom. Na Löblovu reakciu ako prvý odpovedal Eduard Friš a pozastavil sa najmä nad jeho hodnotením konformizmu, ktorý mal mat' iný obsah v kapitalistickej a iný v socialistickej spoločnosti. Pre Friša konformizmus „,vyznačuje najskôr malomeštiaka, na rozdiel od proletára, ktorý máva $k$ veciam vztah uvedomelý. Pravda, konformizmus môže sa sporadicky objavovat' i medzi robotnikmi, ba i v socialistickej spoločnosti, ale nemyslime si, že tým dostáva automaticky charakter revoluč$n y$ “. Friš na rozdiel od Löbla tvrdil, že konformizmus je v podstate „buržoázny prežitok", ktorý nepatrí do komunistickej spoločnosti a ak aj Gide našiel v sovietskej spoločnosti prvky konformizmu, je to zaiste iba dočasný jav. Pretože „,v krajine ktorá raz navždy zúčtovala s mocnost'ami tmárstva a reakcie, ktorá dviha sociálnu úroveň i vedomie svojho obyvatel'stva, ktorá prebúdza $k$ životu po stáročia utláčané národy a otvára nové obzory pred nimi, v takomto organizme spoločenskom je síce možný konformizmus ako jav prechodný, ale rozhodne nie

52 LES, J. Môžu sa dovolávat' Gide-a? In Slovenské zvesti, 25. 12. 1936, s. 1.

53 LES, J. Odpoved' A. Gideovi. Bratislava: Nákladom Sväzu priatel’ov SSSR, b. r., s. 10.

54 LES, ref. 53, s. 24-25.

55 LES, ref. 53, s. 10. 
ako činitel’ určujúci povahu, ráz a celkové ovzdušie krajiny “, písal optimisticky vtedy ešte študent Právnickej fakulty Univerzity Komenského. ${ }^{56}$

K Frišovej reakcii pripojila redakcia DAV-u vlastný krátky komentár. Redakčný článok síce ocenil Löblovu snahu ,,zhodnotit’ sovietsku skutočnost' ideologickými závermi“", no vyčítal autorovi, že ani on si ešte neosvojil dostatočne marxistickú metódu, ktorou jedine možno správne posudzovat' sovietsku skutočnost'. ${ }^{57}$ Ďalšie reakcie na Gideovu knihu potom mali príst' v nasledujúcich číslach, no časopis $D A V$ už odvtedy nevyšiel a diskusia bola zrejme vedením Komunistickej strany ukončená, ked’že nepokračovala ani v Slovenských zvestiach.

Jedinou reakciou z liberálno-demokratického tábora na Návrat ze Sovětského svazu bola recenzia Hany Gregorovej v Slovenských smeroch z novembra 1937. Gregorová podl'a vlastných slov nerozumela pobúreniu, ktoré táto brožúrka vyvolala, a vysvetl'ovala to Gideovým zbytočným hyperkriticizmom. A podobne ako ostatní recenzenti sa venovala najmä údajnému umlčiavaniu kritiky. ,,Možno tvrdit', že v SSSR niet kritiky, ked' tu kvitne satira? A že sa nedbá o to, čo sa $v$ cudzine deje? Áno, nestojí Rusko v medzinárodnej politike ako dôležitý faktor, nestará sa o to, aby l'udstvo spelo k sociálnej spravodlivosti, nestará sa o svetový mier? " pýta sa Gregorová a neobišla ani Gideom kritizovanú uniformitu obyvatel'ov ZSSR, ktorú však takisto prevrátila naruby a interpretovala ako občiansku cnost'. „, Gidea trápi, že je sovietsky občan spokojný so zeleninou a ovocím, aké na trhu má a ktorá sa jemu, južným ovocím rozmaznanému Francúzovi, zdá byt' zlou. [...] Bez reptania stojí vo fronte za potravinami a Gidea to pohoršuje, lebo sa mu zdá, že týchto l'udí ani konformizmus nemrzí. Toto všetko by vlastne človeka malo len nadchnút', obdivovat' by mal dobrú vôl'u vychovaného občana. Kol'ko nepochopenia vôbec pre občiansku výchovu ... " zhŕňa Gregorová a nakoniec dodáva: „Všetky výčitky Gidea Sovietskemu zväzu možno podobne odmietnut', hoci v polosne. " 58 Celkovo sa tak zdá, že Gregorovej text ani nie je recenziou, skôr obhajobou vnútornej (i zahraničnej) politiky Stalina a predstavitel’ov Sovietskeho zväzu. Ďalší slovenskí spisovatelia a umelci sa ku komentáru Gideovej knihy neodhodlali.

V českom prostredí, naopak, mimoriadne pozitívne recenzoval Návrat zo Sovietskeho zväzu literárny kritik Václav Černý. ${ }^{59}$ Vo svojom článku rázne odsúdil

56 FRIŠ, Edo. Gideovske dozvuky. Poznámka na okraj knihy J. Lesa „Odpoved’ André Gideovi“. In $D A V, 1937$, roč. 9, č. 1, s. 4-5.

57 DAV. Gideovske dozvuky. In $D A V, 1937$, roč. 9, č. 1, s. 5.

58 GREGOROVÁ, Hana. André Gide: Návrat zo Sovjetského sväzu (recenzia). In Slovenské smery, 1937, roč. 4, č. 5, s. 194-197. Porovnaj aj d’alšie recenzie tentokrát sovietskej socialisticko-realistickej literatúry od tejto autorky: GREGOROVÁ, Hana. „Ked' sa kalila ocel'“. In Slovenské smery, 1937, roč. 4, č. 8, s. 310-315; GREGOROVÁ, Hana. Ruské žalospevy. In Slovenské smery, 1937, roč. 4, č. 9-10, s. 391-392.

59 Václav Černý (1905 - 1987) - český literárny vedec, filozof, prekladatel' a účastník proti- 
komunistickú ideológiu a jej domácich obhajcov a podobne ako Gide prirovnal stalinistickú kultúrnu politiku k tej nacistickej. Na záver úvahy napísal: „,Nacismus a stalinismus urážejí v člověku vše, co je podstatou a důstojností jeho lidstvi! "60 Rovnako tvrdým spôsobom kritizovali stalinskú kultúrno-politickú prax tej doby aj František Xaver Šalda ${ }^{61}$ alebo Ferdinand Peroutka. ${ }^{62}$ A hoci si českí liberálni intelektuáli uvedomovali zahranično-politickú situáciu a postavenie Československa v medzinárodnej politike, napriek tomu sa dokázali zastat’ svojich umeleckých či intelektuálnych kolegov a odmietali potlačovat' kritiku stalinskej praxe len kvôli ohl'adom na československo-sovietske spojenectvo. ${ }^{63}$

V komunistickom prostredí zaznela ostrá kritika českého vydania Gideovej knihy najmä z úst straníckych ideológov. Najradikálnejšiu a zároveň najvulgárnejšiu odpoved' francúzskemu spisovatel'ovi napísal český komunistický kritik Stanislav K. Neumann ${ }^{64} \mathrm{v}$ práci Anti-Gide neboli optimismus bez pověr a ilusí. ${ }^{65}$ Pre ortodoxných komunistických ideológov boli aj reakcie v časopise $D A V$ pramálo kritické, polovičaté či dokonca „reakčné“, ked’že podl'a ich mienky bola

nacistického odboja za druhej svetovej vojny. Počas komunistického režimu bol na prelome rokov 1952 a 1953 niekol'ko mesiacov väznený a mal zákaz publikačnej činnosti. Signatár Charty 77 a šéfredaktor časopisu Kritický měsičník v rokoch 1938-42 a 1945-48. BRABEC, Jiří a kol. Slovník zakázaných autori̊ 1948-1980. Praha: Státní pedagogické nakladatelství, 1991, s. 57. ISBN 8004254179.

60 ČERNÝ, Václav. Humanista Gide a staliniský komunismus. Nad poslední Gideovou knihou. In ČERNÝ, ref. 1, s. 149-152.

61 František Xaver Šalda $(1867$ - 1937) - bol český literárny kritik, spisovatel' a publicista. Jedna z vedúcich osobností českého intelektuálneho života pred prvou svetovou vojnou, ako aj v medzivojnovom období. V rokoch 1928 - 1937 vydával legendárny Šaldův zápisník. K osobnosti F. X. Šaldu a jeho vzt'ahu k slovenskému umeleckému prostrediu pozri viac: JAKSICSOVÁ, ref. 30, s. 58-61.

62 Ferdinand Peroutka (1895 - 1978) - český spisovatel' a publicista. Jeden z najvýznamnejších predstavitel'ov českej žurnalistiky v medzivojnovom období. Od roku 1924 do roku 1938 pôsobil ako šéfredaktor časopisu Přitomnost. Počas druhej svetovej vojny bol väznený v koncentračnom tábore Buchenwald. Po komunistickom prevrate vo februári 1948 emigroval z Československa a bol jedným zo zakladajúcich členov Rady slobodného Československa. V rokoch 1951 - 1961 viedol české oddelenie rádia Slobodná Európa v Mníchove. Pozri aj: BRABEC, ref. 59, s. 339.

63 PFAFF, ref. 5, s. 21-23.

64 Stanislav Kostka Neumann (1875 - 1947) - český novinár, básnik a literárny kritik. V 20. rokoch patril medzi spoluzakladatel'ov Komunistickej strany Československa, no po nástupe Klementa Gottwalda do čela KSČ koncom 20. rokov bol zo strany vylúčený pre nesúhlas so zvolením jej nového vedenia. V druhej polovice 30. rokov opät' zastával zhodné stanoviská so straníckymi ideológmi a po krátkom čase bol prijatý spät' do komunistickej strany.

65 NEUMANN, Stanislav K. Anti-gide neboli optimismus bez pověr a ilusí. Praha: Lidová kultura, 1937. Túto knihu privítali aj Slovenské zvesti, ktorých zodpovedným redaktorom bol vtedy Ladislav Novomeský. Pozri: J. Anti-Gide. In Slovenské zvesti, 7. 7. 1937, s. 6. jm. Ešte o najúspešnejšej knihe LK. In Slovenské zvesti, 8. 10. 1937, s. 6. 
táto brožúra otvoreným útokom na jedinú socialistickú krajinu. Neumann tak svojou kritikou preniesol do československého diskurzu vulgárne tézy stalinistickej kultúrnej politiky a z týchto pozícií kriticky napadol moderné československé umenie (v jeho a sovietskej terminológii „formalistickéc), pričom prorokoval, že toto umenie, ktoré sa „odtrhlo od l'udu“, je pred zánikom. ${ }^{66}$

Vo svojich ,polemikách“ pokračoval Neumann aj v českojazyčných komunistických periodikách Tvorba a Lidová kultura. Jeho urážky a vylučovanie jednotlivých tvorcov z moderného umenia však nielen pobúrili českých avantgardných umelcov, no rozdelili aj komunistických spisovatel'ov hlásiacich sa vtedy k socialistickému realizmu a vydávajúcich spomínaný časopis $U-B l o k{ }^{67}$ A dokonca sa od Neumannových dogmatických hodnotení dištancoval začiatkom roku 1938, v mene strany, aj člen ÚV KSČ Viliam Široký. ,,Strana nedekrétuje nejaký umelecký smer [...] pri rešpektovani volnosti prejavu oceňuje antifašistických bojovníkov z radov spisovatel'ov, bez toho, aby v umeleckých otázkach žiadala názorovú uniformitu. Nepredpisovali sme nikdy a nikdy tiež nemienime predpisovat', ako má umelec tvorit' a aké formy má volit." "68

Hoci spor vnútri českej avantgardy mal hlbšie, najmä neumelecké, a teda politické súvislosti, útok S. K. Neumanna na českú avantgardu (a moderné umenie vôbec) mal už v nasledujúcom roku dohru v podobe rozpustenia českej surrealistickej skupiny (blízkej Komunistickej strane) jedným z jej umeleckých lídrov Vítězslavom Nezvalom. ${ }^{69}$ Zrušenie činnosti skupiny bolo publikované v komunistickej Tvorbe, no už o pár dní sa väčšina členov skupiny na čele s Karlom Teigem ${ }^{70}$ dištancovala od tohto svojvol'ného Nezvalovho kroku. Rozpustenie skupiny bolo na schôdzi českých surrealistických umelcov konanej 14. marca 1938 odmietnuté a umelci hlásiaci sa k surrealizmu nakoniec vylúčili zo svojho okruhu práve Nezvala. Roztržku s komunistickými umelcami a ideológmi

66 K tomu pozri: KUSÁK, ref. 20, s. 129.

67 PFAFF, ref. 5, s. 96-97.

68 Cit. podl'a: PFAFF, ref. 5, s. 109.

69 Vítězslav Nezval (1900 - 1958) - český básnik a prozaik. Jedna z vedúcich osobností českej avantgardy prvej polovice 20. storočia. V 30. rokoch založil českú surrealistickú skupinu, ktorú svojvol'ne rozpustil v roku 1938. Člen KSČ od roku 1924, po komunistickom prevrate v roku 1948 patril medzi hlavných aktérov pofebruárovej kultúrnej politiky. Pozri aj: DRÁPALA, ref. 14, s. 175-218.

70 Karel Teige $(1900$ - 1951) - český literárny kritik, estetik a teoretik. Jeden z hlavných organizátorov českého umeleckého života $\mathrm{v}$ medzivojnovom období, neúnavný propagátor avantgardných umeleckých smerov, najmä poetizmu a surrealizmu. V 30. rokoch sa rozišiel s komunistickým hnutím pre dogmatické postoje stalinistických ideológov v otázkach kultúry a umenia. Po druhej svetovej vojne, ale najmä po komunistickom prevrate, sa stal predmetom nenávistných kampaní v komunistickej tlači a mal zákaz publikačnej činnosti. V októbri 1951 predčasne zomrel. 
potom zavŕšil Teige publikovaním známeho diela Surrealismus proti proudu, ktorým sa tento talentovaný literárny kritik rozišiel s oficiálnym sovietskym umením. $^{71}$

Spor vnútri českej avantgardy je už popísaný vo viacerých historických štúdiách, preto sa mu bližšie nebudem venovat'. ${ }^{72}$ Zaujímavý je však postoj slovenských či po slovensky píšucich umelcov k vyššie uvedeným diskusiám. Redaktor kultúrnej rubriky Robotníckych novín Josef Dvořák (ktorý písal pod značkou $\mathrm{Jdv}.)^{73}$ napísal, že „pozorného sledovatel’a vývoja našej poézie neprekvapí, že Vitězslav Nezval utiekol od vztyčenej zástavy". Rozpustenie surrealistickej skupiny Dvořák jednoznačne privítal, ked’že ,surrealizmus, ako sa vyvinul v našej poézii, [...] ukázal sa byt’ za roky svojej existencie smerom neplodným ".74 Samozrejme, autorov názor, že avantgardná poézia ako umelecký smer tvorivo stagnuje, je úplne legitímny. Dôležité však je, že autor tu nepostrehol politické pozadie daného sporu, teda rozchod českej avantgardy s komunistickou stranou v dôsledku vnášania stalinistických metód do kultúrnej politiky KSČ. Nezval sa totiž snažil o rozpustenie surrealistickej skupiny z toho dôvodu, aby sa dištancoval od tvrdej kritiky svojich surrealistických kolegov, ktorí protestovali proti perzekúciám sovietskych umelcov a zásahom cenzúry do ich diel. Tým, že Dvořák zjednodušil spor medzi českými avantgardistami na čisto umeleckú oblast', zrelativizoval aj snahu surrealistov o zamedzenie prenášania sovietskej praxe do kultúrnej politiky KSČ (i ostatných socialistických strán).

Málo známy je postoj slovenských nadrealistov, ktorí sa hlásili k akejsi slovenskej variante surrealizmu a v spomínanom spore sa niektorí z nich postavili na stranu K. Teigeho a d’alších českých surrealistov. ${ }^{75}$ Do Teigeho publikácie Surrealizmus proti proudu, ktorá vyšla v máji 1938, pripojili svoje podpisy Michal Považan, Rudolf Fábry, Vladimír Reisel a Móric Mittelmann Dedinský. In-

71 KUSÁK, ref. 20, s. 121-123.

72 Najpodrobnejšie: KUSÁK, ref. 20, s. 110-135; DRÁPALA, ref. 14, s. 175-218.

73 VOPRAVIL, Jaroslav. Slovník pseudonymů v české a slovenské literatuře. Praha: SPN, 1973, s. 144.

74 Jdv. Konec surrealistickej poézie. In Robotnicke noviny, 20. 3. 1938, s. 2.

75 Problematikou slovenských nadrealistov sa z najnovších prác zaoberá rozsiahly literárno-vedný zborník Nadrealizmus. Avantgarda 38, ktorého zostavovatel'om bol literárny kritik Milan Hamada. Ich postoje k rozpusteniu českej surrealistickej skupiny si však zborník nevšíma. Bližšie pozri: HAMADA, Milan (ed.). Nadrealizmus. Avantgarda 39. Bratislava: Kalligram; Ústav slovenskej literatúry SAV, 2006, 680 s. ISBN 807149917. Z historikov sa slovenským nadrealistom vo svojich prácach venovala najmä Vlasta Jaksicsová. K tomu pozri: JAKSICSOVÁ, ref. 30, s. 97-114 a s. 130-135. Okrajovo o nadrealistoch písal aj Ján Mlynárik. Pozri: MLYNÁRIK, Ján. Slovenský nadrealizmus v metamorfózach stalinizmu. In ,,Spoznal som svetlo a už viac nechcem tmu ... “ Pocta Jozefovi Jablonickému. Ed. Norbert Kmet'. Bratislava: VEDA, 2005, s. 143-182. ISBN 8022408158. 
formovali v nej čitatel'ov, že slovenskí surrealisti zaujali spoločné stanovisko so svojimi pražskými a parížskymi kolegami. ${ }^{76}$

V poslednom čísle literárneho časopisu Slovenské smery ${ }^{77}$ (išlo o trojčíslo z mája až júla 1938), ktoré vyšlo pred ich nedobrovol’ným zastavením autonomistickou Tisovou vládou, dostali po prvýkrát významný priestor aj slovenskí nadrealisti. „Protiformalistickej“ kampani vedenej proti umelcom v Sovietskom zväze ani čistkám sovietskych avantgardistov sa v časopise nevenovali, hoci v príspevkoch Jána Mukařovského ${ }^{78}$ či Michala Považana je badatel'né vymedzenie sa voči vulgárnym metódam pri hodnotení umenia, aké používal S. K. Neumann. ${ }^{79}$ Vlastné, samostatné postoje k súdobej sovietskej skutočnosti ale neformulovali a k Teigeho občianskej odvahe, akú ukázal vydaním hore uvedenej knihy, sa ani zd’aleka nepriblížili.

\section{Do seba zahl'adené občianske dozrievanie slovenskej literárnej obce}

Niektoré zl'ahčujúce reakcie slovenskej kultúrnej obce na Vel'ký teror, no najmä jej mlčanie, je naozaj prekvapivé, ked’že slovenskí spisovatelia neboli apolitickí. Práve naopak, otvorene zastávali politické postoje, boli reprezentantmi rozličných politických prúdov a nezriedka zasahovali svojimi komentármi do politického diania a politických sporov. Myslím, že jedna z odpovedí na otázku nereagovania, resp. bagatelizovania sovietskych čistiek tkvie aj $v$ atmosfére slovenského kultúrneho prostredia, ktoré sa viac zaoberalo vlastnými problémami a ktoré charakterizovali najmä t’ažko prekonatel'né názorové (i osobné) rozpory medzi literátmi, hoci nezanedbatel'ným faktorom bola aj súdobá medzinárodná situácia.

Názorové konfrontácie literátov obzvlášt’ úzko súvisia s obsahom predchádzajúcich riadkov. Spisovatel'ské polemiky boli v prvom rade o slobode umeleckej tvorby a konflikty vznikali najmä pri snahách o presadzovanie mimoumeleckých (t. j. politických) princípov do umeleckého života. Dozvuky zahraničných kampaní proti tzv. formalizmu či najmä z Nemecka sa šíriacej kampane proti

76 K tomu pozri: Michal Považan M. Bakošovi z Prahy 4. 4. 1938. In Slovenské pohl’ady, 1964, roč. 80 , č. 9 , s. 77 . V Teigeho brožúre Surrealismus proti proudu som však zmienku o slovenských nadrealistoch/surrealistoch a ich postoji k danému sporu nenašiel. Porovnaj: TEIGE, Karel. Surrealismus proti proudu. Praha: Surrealistická skupina, 1938, 76 s.

77 Časopis Slovenské smery bol oficiálnym orgánom Spolku slovenských spisovatel'ov. Redigovali ho predseda spisovatel'ského spolku Ján Jesenský a tajomník spolku Emil Boleslav Lukáč.

78 Jan Mukařovský (1891 - 1975) - český jazykovedec a literárny teoretik, predstavitel' českého štrukturalizmu. V 30. rokoch pôsobil na Univerzite Komenského v Bratislave.

79 MUKǍ̌OVSKÝ, Jan. K noetice a poetice surrealizmu v maliřrství. In Slovenské smery, 1938, roč. 5, č. 6-8, s. 226-230; POVAŽAN, Michal. O tzv. skutočnosti v umení. In Slovenské smery, 1938 , roč. 5, č. 6-8, s. 274-280. 
„Zvrhlému umeniu“ $\mathrm{z}$ druhej polovice 30. rokov dorazili, hoci $\mathrm{v}$ jemnejšej podobe aj na Slovensko. Jedným z hlavných konfliktných bodov, ktorý sa objavil v mnou sledovanom období, bol dnes už takmer zabudnutý spor Spolku slovenských spisovatel'ov s niektorými predstavitel'mi Matice slovenskej (MS) a Jánom Pöstényim - správcom Spolku sv. Vojtecha (a tiež člena výboru MS). Nebudem sa tu obšírne zaoberat' týmto sporom, uvádzam ho len na ilustráciu atmosféry v slovenskom kultúrnom živote a zameriam sa len na jeho dopady na spisovatel'skú obec.

Genéza tohto konfliktu začala ešte na začiatku roku 1936, ked' počas návštevy delegácie Matice slovenskej v Spojených štátoch amerických odoslal katolícky kňaz Msgr. Ján Pöstényi šestnástim americkým kňazom dôverný list, v ktorom ich upozorňoval na niektoré „mravne závadné“ knihy vydané Maticou slovenskou a rovnako v ňom kritizoval aj jej vydavatel'skú a edičnú prax. ${ }^{80}$ Tento prípad rozprúdil vášnivú diskusiu na stránkach slovenských novín v októbri toho istého roku po návrate matičnej delegácie do Československa a počas zasadnutia matičného výboru, ktorý na schôdzi prerokoval aj Pöstényiho list, na verejnosti ešte stále neznámy. ${ }^{81}$

Schôdza výboru MS bola neverejná, a tak o tam prerokovaných otázkach vychádzali v mnohých denníkoch rozličné neoverené správy a dohady. Znepokojivé pre mnohých publicistov bolo, ked' postupne vychádzalo najavo, že niektorí členovia výboru obraňovali, či sa dokonca stotožňovali s Pöstényiho stanoviskom. Skutočnost', že niektorí matiční predstavitelia sa snažili presadit' zákaz publikovania pre určitých autorov v matičnom vydavatel'stve, popudila viacerých slovenských spisovatel'ov, ktorí to vnímali ako obdobu snáh, ktoré videli v nacistickom Nemecku v prípade „Entartete Kunst“ a dožadovali sa náležitého vysvetlenia. Následkom toho publikovali v októbri 1936 Janko Jesenský a Emil Boleslav Lukáč, prvý ako predseda a druhý ako tajomník Spolku slovenských spisovatel'ov (SSS), Otvorený list Správe Matice slovenskej, v ktorom sa okrem iného pýtali, či ,je pravda, že na schôdzi výboru Matice slovenskej ustanovila sa komisia preskúmat', či sú diela slovenských spisovatel'ov, ako sú Mitrovský, Jesenský, Jégé, Chrobák nemravné ". ${ }^{82} \mathrm{Na}$ tento list odpovedala v tlači Správa Matice slovenskej, že nijakú komisiu pre posudzovanie mravnosti, resp. nemravnosti literatúry nezriadila, avšak ustanovila inú komisiu, o ktorej však ,nemôže

80 Celú kauzu podrobne sledoval napr. nezávislý dvojtýždenník Politika. Pozri: Čo napísal msgr. Ján Pöstényi kňazom do Ameriky? In Politika, 1. 10. 1936, s. 200-203.

81 MRÁZ, Andrej. O žabomyšej vojne pre mrzkost' v literatúre. In Slovenské pohl'ady, 1936, roč. 52, č. 2, s. 126-128; Čo sa to robí v Matici slovenskej? In Politika, 15. 10. 1936, s. $217-$ 218. R. Mravnost' v literatúre a úcta k osobnostiam v živote. In Kultúra, 1936, roč. 8, č. 12, s. $562-563$.

82 SMREK, Ján. SSS a Matica Slovenská. In Elán, 1936, roč. 7, č. 3, s. 9-10. 
dat' podrobnejšie vysvetlenie, ked’že zasadnutie výboru bolo prísne dôverné". A taktiež Správa MS ,nepokladá za potrebné oznámit' Spolku slovenských spisovatel'ov mená členov komisie, ktorí majú osobitné personálne poslanie, lebo táto vec sa týka iba interných vecí ústavu, do ktorých inému spolku neprichodí sa miešat". Znenie tohto matičného listu vedenie spisovatel'ského spolku v nasledujúcej odpovedi odmietlo a ohodnotilo ako nedostatočné..$^{83}$

Do tejto mimoriadne konfliktnej diskusie sa napokon zapojil aj šéfredaktor Elánu Ján Smrek. Tento básnik považoval spôsob, akým celú túto aféru riešilo vedenie SSS za vel'mi nešt’astný a unáhlený, najmä z prestížnych dôvodov, ked'že Matica slovenská mala v slovenskej spoločnosti vážené postavenie. ${ }^{84}$ (Túto skutočnost' zneužili l'udácke denníky a označili spisovatel'ské listy ako vykonštruovaný útok proti Matici slovenskej.) ${ }^{85}$ Smrek potom na jednom zo zasadnutí spisovatel'ského spolku skoncipoval nový otvorený list Matici slovenskej, ktorý ale väčšina členov výboru Spolku odmietla ako príliš nekritický a rozhodla sa publikovat' vlastnú kritickú odpoved'. ${ }^{86}$ Myslím, že v tomto prípade postupoval Smrek dost' neuvážene a jednostranne, ked’ žiadal nápravu situácie iba od spisovatel'skej obce.

Celý tento spor medzi MS a SSS nakoniec zostal nedoriešený, avšak spisovatel'ská obec zostala po ňom rozdelená na nepriatel'ské tábory. ${ }^{87}$ Takmer celý rok 1937 potom zapíňal spor medzi Jánom Smrekom a Gejzom Vámošom (ako hlavným kritikom MS) stránky Elánu a Slovenských smerov, no i d’alších periodík, v ktorom už nešlo o slobodu tvorby či o otázky „mravnej“, resp. „nemravnej“ literatúry, ale dostal výrazne osobnú podobu. ${ }^{88}$ Vyhrotený konflikt oboch spisovatel'ov prešiel napokon aj na ostatných redaktorov a prejavoval sa dokonca

83 Znenia oboch listov a aj d'alšia odpoved' SSS sú publikované v Slovenských smeroch. Pozri: Čo sa robí v Matici slovenskej? In Slovenské smery, 1936, roč. 4, č. 2, s. 78-80; TAJOVSKÝ, Jozef Gregor. Matica slovenská a Spolok slov. spisovatel'ov. In Slovenské smery, 1936, roč. 4, č. 3, s. 116; Matica slovenská odpovedala. In Politika, 1. 11. 1936, s. 229-230.

84 SMREK, Ján. Z interných a verejných vecí SSS. In Elán, 1936, roč. 7, č. 4, s. 11-12.

85 Pozri: R. „Už svojím jestvovaním prekážajú...“"In Slovenské smery, 1937, roč. 4, č. 8, s. 318; VÁMOŠ, Gejza. Občianska relácia. II. čast'. In Pero, december 1937, s. 5; CLEMENTIS, Vlado. „Kulturbolschevismus“. In Slovenské zvesti, 8. 11. 1936.

86 SMREK, Ján. Z interných a verejných vecí SSS. In Elán, 1936, roč. 7, č. 4, s. 11-12.

87 Samozrejme netvrdím, že toto bol jediný dôvod osobnej nevraživosti medzi spisovatel'mi.

88 j. s. Program kongresu slovenských spisovatel'ov. In Elán, 1936, roč. 7, č. 7, s. 12; j. s. Prekvapí nás Gejza Vámoš? In Elán, 1937, roč. 7, č. 8, s. 12; SMREK, Ján. Fixná idea Gejzu Vámoša. In Elán, 1937, roč. 7, č. 9, s. 12; SMREK, Ján. Umývanie murína. In Elán, 1937, roč. 7, č. 10, s. 12; SMREK, Ján. Zas l’adový obkladok. In Elán, 1937, roč. 8, č. 2, s. 11; VÁMOŠ, Gejza. Spor Zlaty Dančovej. In Slovenské smery, 1937, roč. 4, č. 8, s. 317-318; VÁMOŠ, Gejza. Úvahy o pravej a nepravej kritike. In Slovenské smery, 1937, roč. 4, č. 9-10, s. 387-390; VÁMOŠ, Gejza. List. In Slovenské smery, 1937, roč. 5, č. 1, s. 38-40. L. K jednej polemike. In Slovenské smery, 1937, roč. 5, č. 2, s. 79. J. O. Literáti medzi sebou. In Pero, október 1937, s. 4. 
aj $\mathrm{v}$ recenziách diel, ktoré tvorili pravidelné rubriky kultúrnych časopisov. Ak napríklad v Eláne vyšla o nejakej knihe priaznivá recenzia, tak v Slovenských smeroch vyšlo spravidla negatívne hodnotenie a naopak. ${ }^{89}$

Aby som sa však vrátil $\mathrm{k}$ ústrednej otázke položenej v predchádzajúcich riadkoch: prečo slovenskí umelci zl’ahčovali pomery v Sovietskom zväze a nesolidarizovali so svojimi umeleckými kolegami, ktorí boli vystavení nel'udským perzekúciám? Prečo najmä l’avicoví či politicky nezaradení spisovatelia a obdivovatelia ruskej/sovietskej kultúry a umenia, ako spomenutý E. Šándor, G. Vámoš, J. Dvořák, H. Gregorová (i d’alší nespomenutí), radšej obdivovali východného spojenca, než by ho kritizovali, na rozdiel od svojich českých kolegov (K. Teige, F. Peroutka, V. Černý, F. X. Šalda a d’alší) alebo napr. aj slovenských novohlasistov? ${ }^{90}$ Prečo spisovatelia mlčali aj vtedy, ked' mlčat' nemali, ked' boli popravení aj ich priatelia (ako napr. spisovatel' Sergej Tret’jakov), s ktorými sa zoznámili pri návšteve sovietskych spisovatel'ov v Bratislave? Prečo Slovenské smery, ako ústredný orgán SSS, nepublikoval žiadne prehlásenie, ktoré by solidarizovalo s prenasledovanými umelcami v Sovietskom zväze, napriek tomu, že sa spisovatelia na svojom 1. kongrese v júni 1936 zaviazali, že „, budú bránit’ vydobyté hodnoty slobody, nech by už na ne siahal barbarský nepriatel' tu, či v zahranič́ [zvýraznil - F. P.] "? ${ }^{91}$ Prečo si aj divadelníci čistky v divadle úmyselne nevšímali alebo ich bagatelizovali? ${ }^{92}$ A vôbec, prečo sa neozvali ani výtvarníci, napr. pri cenzúre československej výstavy v Moskve alebo hudobní skladatelia pri cenzúre Šostakovičovej opery, ktorú slovenské denníky pozitívne privítali?

Nechystám sa podat' žiadnu všeobsiahlu odpoved', ponúkam iba jedno z možných vysvetlení, ktoré by mohlo objasnit' niektoré, no zd’aleka nie všetky, po-

89 Andrej. Martin Rázus. Odkaz mŕtvych (recenzia) In Slovenské pohl’ady, 1936, roč. 52, č. 10, s. 558-560; VÁMOŠ, Gejza. Poznámky k novému smelému dielu. In Slovenské smery, 1938, roč. 5, č. 5, s. 190-193; MEČIAR, Stanislav. Moja odpoved'. In Slovenské pohl'ady, 1938, roč. 54, č. 1, s. 58-59; BAKOŠ, Nikolaj. Odpoved' na odpoved' Stanislava Mečiara. In Slovenské pohl'ady, 1938, roč. 54, č. 2, s. 128; MEČIAR, Stanislav. Literárna tvorba v závoze. In Slovenské pohl'ady, 1938, roč. 54, č. 3, s. 189-12.

90 K tomu pozri: -frmk-. Poznámky na okraj moskovského procesu. In Nový hlas, 1936, roč. 4, č. 7, s. 105. Novohlasisti boli príslušníci mladej generácie slovenských sociálnych demokratov, ktorí boli v značnej opozícii voči svojmu (pre nich príliš konzervatívnemu) vedeniu. Od februára 1933 do apríla1937 vydávali vlastný časopis Nový hlas a v prednáškovej činnosti na bratislavských fakultách odsudzovali sovietske monsterprocesy. Bližšie k Novohlasistom pozri: KAMENEC, Ivan. Novohlasistická skupina v sociálnodemokratickej strane na Slovensku. In KAMENEC, Ivan. Hladanie a blúdenie v dejinách. Bratislava: Kalligram, 2000, s. 39-47. ISBN 8071493538.

91 Pozri Manifest slovenských spisovatel'ov publikovaný napr. v: CHMEL, Rudolf (ed.). Kongres slovenských spisovatel’ov 1936. Bratislava: Tatran, 1986.

92 PAVLOVÁ-KRNOVÁ, Féd’a. Osud Meyerholdovho divadla. In Elán, 1938, roč. 8, č. 7, s. 6; Borodáč o sovietskom divadle. In Slovenské zvesti, 22. 2. 1937, s. 6. 
hnútky osobností slovenskej kultúry a okolnosti, ktoré vplývali na to, aké stanoviská zverejňovali. Rozhodujúcou skutočnost'ou podla môjho názoru bola obava l'avicových a liberálno-demokratických literátov a sympatizantov ZSSR, že kritikou sovietskych čistiek a perzekúcií (resp. už uznaním ich existencie), by mohli posilnit' svojich osobných, názorových a politických oponentov z radov l'udáckych publicistov alebo aj niektorých redaktorov z okolia mesačníka Elán.

Domnievam sa, že podla vtedajších predstáv Šándora, Vámoša, Dvořáka, Gregorovej a d'alších by zverejňovaním informácií o sovietskych čistkách, príp. publikovaním pochybností o dianí v Sovietskom zväze, dávali (spolu s redakciou Slovenských smerov a aj so Spolkom slovenských spisovatel'ov) za pravdu A. Machovi a l’udáckym či matičným kampaniam proti „kulturbol'ševizmu“ a proti „nemravnej literatúre“. ${ }^{93}$ A zrejme boli presvedčení o tom, že kritikou sovietskej politiky by posilnili ich politicko-mocenské pozície v zápase, ktorý sa odohrával vo vtedajšom Československu. V období, ked'sa v pravicových fašistických diktatúrach konali verejné zastrašovacie kampane proti „,zvrhlému umeniu“ a spisovatelia, umelci a vedci z Nemecka, Talianska, Španielska, Pol'ska boli perzekvovaní, v čase, ked' ozveny tejto kampane prenikali aj na Slovensko, tak $\mathrm{v}$ tejto dobe potrebovali l'avicoví umelci a obdivovatelia ruskej/sovietskej kultúry verit' v svojho „východného spojenca“ a nie ho ohrozovat' pre nich asi zbytočnou kritikou. Skutočnost', že svojím mlčaním a relativizovaním Vel'kého teroru aj oni prispeli k udržaniu ilúzií o slobode a demokracii v Sovietskom zväze, a to zrejme až do čias po druhej svetovej vojne, ${ }^{94}$ si neuvedomovali alebo nechceli uvedomit'.

Samozrejme je dobre známe, že mnohí slovenskí umelci tak v predchádzajúcom období, ako aj v tom, ktoré som sledoval, boli členmi politických strán, vysokopostavenými úradníkmi, príp. umelcami s politickými ambíciami. V prípade aktívnych politikov by boli ich pragmatické politické stanoviská (napr. v prípade hodnotenia sovietskych monsterprocesov), presadzované vzhl'adom na súdobú „reálpolitiku“, úplne legitímne. Avšak nemyslím si, že by tomu tak malo byt’ aj v prípade umelcov vyznávajúcich slobodu tvorby a manifestačne vyhlasujúcich vernost' vel'kým ideálom l’udstva.

93 Porovnaj: R. „Už svojím jestvovaním prekážajú ...“. In Slovenské smery, 1937, roč. 4, č. 8, s. 318; MACH, Šaňo. Bol’ševickí kamaráti, a čo teraz? In Slovák, 9. 2. 1936; KÖRPER, Karol. Úlohy katolíckych Slovákov. In Kultúra, 1936, roč. 8, č. 1, s. 29.

94 K tomu porovnaj: ZAVACKÁ, Katarína. Cenzúra v Československu v rokoch 1945 - 1948. In Československá historická ročenka, 2000, s. 555-556. ISSN 1214-8334. 


\title{
REAKTIONEN DER SLOWAKISCHEN KULTURGEMEINDE AUF DIE SOWJETISCHE KAMPAGNE GEGEN \\ DEN SOG. FORMALISMUS IN DER KUNST IN DEN JAHREN 1936-1938
}

\section{FILIP P A V Č Í K}

Die vorliegende Studie befasst sich, basierend auf der Erforschung der slowakischen literarischen und kultur-politischen Periodiken, mit den Reaktionen der slowakischen Kulturkreise auf die sowjetische Kampagne gegen den sog. Formalismus in der Kunst. Mit dieser propagandistischen Kampagne, die Bestandteil des Großen Terrors war, begannen die Vertreter der Sowjetunion 1936 mit dem Hauptziel, eine Säuberung im sowjetischen Kultur- und Kunstleben durchzuführen und damit den, für das Regime unbequemen Künstlern, loszuwerden. Obwohl die Säuberung ein außergewöhnliches Aufsehen im gesamten Europa hervorrief, die slowakischen Persönlichkeiten der Kultur und Kunst reflektierten kaum den offenen Angriff auf die moderne und avantgardistische Kunst. Und während im tschechischen Umfeld die Ereignisse in der Sowjetunion die Titelseiten der Zeitungen und Zeitschriften füllten, übergehen die slowakischen Periodiken diese Ereignisse mit einem Schweigen. Die Studie weist darauf hin, dass ein der Hauptgründe, warum es so verlief, war auch die Tatsache, dass die slowakischen Kulturkreise zu jener Zeit durch schwer überwindbare Persönlichkeits- und Meinungswidersprüche geprägt waren. Die linken Intellektuellen und Anhänger der Sowjetunion weigerten sich den östlichen Verbündeten der Tschechoslowakischen Republik auch deswegen zu kritisieren, weil sie dadurch in der angespannten internationalen Situation ihre politischen Gegner und Meinungsopponenten aus den Reihen der Ludaken unterstützen würden. Die Tatsache, dass sie durch diese ihre Einstellung die romantischen Illusionen über die Sowjetische Union in der slowakischen Gesellschaft aufrechtzuerhalten verhalfen, nahmen sie nicht wahr oder wollten nicht wahrnehmen.

\author{
Mgr. Filip Pavčík \\ Historický ústav SAV \\ Klemensova 19, 81499 Bratislava \\ e-mail: f.pavcik@gmail.com
}

